\title{
空面のグレアが鉛直面のコンピュータ作業の視作業性に及ぼす影響 \\ THE EFFECT OF GLARE FROM WINDOWS \\ ON VISUAL PERFORMANCE FOR VERTICAL VDT TASKS
}

\author{
加藤洋子*, 明石行生 ${ }^{* *}$, 菅野 普*** \\ Yoko KATO, Yukio AKASHI and Susumu SUGANO
}

\begin{abstract}
The purpose of this study was to investigate how a high-luminance side window impairs visual performance of a computer task. Subjects were asked to detect targets presented at the central and peripheral visual field, and the subjects' response times were measured. In order to investigate the mechanisms of how window luminance affects target detections, veiling luminance on each target caused by the window was calculated under each of the experimental conditions. The findings of the study are listed below.

1) The high-luminance window behind the computer display significantly impaired the detection performance of targets presented on the computer display. As the luminance of the window increased, the visual performance was decreased. The validity of the experimental dataset was confirmed by comparing the dataset with existing experimental data.

2) When window luminance exceeded a certain luminance between $3000 \mathrm{~cd} / \mathrm{m}^{2}$ and $6000 \mathrm{~cd} / \mathrm{m}^{2}$, visual performance was deteriorated significantly. This implies that window luminance should be reduced to lower than $3000 \mathrm{~cd} / \mathrm{m}^{2}$ for computer tasks.

3) Evaluations of discomfort glare did not necessarily correspond to visual performance. Therefore, in order to design windows for efficient task environments it is important to minimize the effects of windows on discomfort glare and visual performance.
\end{abstract}

Keywords : Glare, Visual Performance, Luminance of Window, Veiling Luminance, Peripheral Vision グレア，視作業性，空面輝度，光幕輝度，周辺視野

\section{1. 背景}

近年，居住者の健康維持や地球温暖化の防止のために，積極的な 昼光の利用が推奨されている。しかし，昼光を取り入れる開口部で ある側空は, 高い輝度を持つためグレア源となり得る. 空面のまぶ しさについては，これまで主として不快グレアの観点から研究が進 められてきた。空面の不快グレアの評価指標として, Predicted Glare Sensation Vote (PGSV)1および Daylight Glare Probability $(\mathrm{DGP}) 2)$ が提案され, それらに基づいて光環境の評価方法が構築され つつある ${ }^{3), 4,5)}$. 一方, 減能グレアについては, これまで屋内照明で はグレア光源が視対象に及ぼす影響が小さいため, 研究がほとんど 進められてこなかった。

しかし，輝度が高く立体角が大きい側空は，例えば，コンピュー タ・スクリーンを使った視作業（以降，コンピュータ作業とよぶ） など鉛直面に視対象が存在する場合には，その視対象の視認性に影 響を与えるはずである。最近では，コンピュータ作業やテレビ鑑賞 といった，鉛直面の視対象を見る場合が多いので，側空が鉛直面に ある視対象の視認性に及ぼす影響は無視できない、今後, 昼光を積
極的に利用寸るうえで, 空面の不快グレアの観点からだけでなく ${ }^{2}$, 減能グレアの観点からも空面輝度の規制のガイドラインを構築する ことは有意義であると考える。

今回，ブラインドやスクリーンにより空面輝度を制御するための 基礎資料を蓄積することを目的として, 減能グレアの観点から空面 の輝度がコンピュータ作業の視作業性にどのような影響を与えるか を調べる実験を行った。具体的には，種々の輝度に設定した空面を 背にしたスクリーンの様々な位置に視標を提示し, 視作業性の指標 として，その視標を検出する時間（以降，反応時間と呼ぶ）と視標 の見落とし率を測定した。つぎに，その実験結果に基づいて減能グ レアの観点から空面の許容限界輝度の提案を試みた。さらに，今回 の実験結果の信頼性を既往研究に基づいて考察した。具体的には, 本実験の各実験条件について, 減能グレアの程度を定量的に評価で きる,グレア光源が視野内に生じる等価光幕輝度 (定義は後述する) を算出した，その等価光幕輝度が視標と背景との輝度コントラスト を低下させる程度を調心゙, 既往研究からその輝度コントラストの低 下の程度を考慮した視標に対応するコントラスト感度を求めた。そ

\footnotetext{
本論文は，参考文献 19)の内容を再構成し，加筆修正したものである。 東京工業大学環境・社会理工学院建築学系 博士後期課程 $\cdot$ 修士 (工学)

** 福井大学学術研究院工学系部門建築建設工学分野 教授・博士 (工学)

*** 旭化成(侏研究開発本部 博士(工学)
}

Grad. Stud., Dept. of Architecture and Building Engineering, School of Environment and Society, Tokyo Institute of Technology, M.Eng

Prof., Dept. of Architecture and Civil Engineering, Graduate School of Engineering, University of Fukui, Ph.D.

Corporate Research \& Development, Asahi Kasei Corporation, Ph.D. 
のコントラスト感度と実験結果とを比較することにより，本実験の データの信頼性を確認した。

\section{2. 実験}

\section{1. 実験設備}

実験は, 幅 $3.7 \mathrm{~m}$, 奥行 $6.4 \mathrm{~m}$, 高さ $2.6 \mathrm{~m}$ の実験室で行った. 実験室の天井，壁，床の反射率は，それぞれ，0.8，0.7，0.4であっ た. 実験室の天井には, 下面開放型照明器具 ( $32 \mathrm{~W}$ の HF 蛍光ラン プ 2 灯用）が 4 台設置されている. 照明器具には, 調光機能がつい ていないため, NDフィルタをランプに巻き付けることにより照明 器具の明るさを調光した，空面は遮光カーテンで覆い屋外からの昼 光が部屋に入らないようにした.

\section{2. 実験装置}

図 1 に実験装置を示す. 実験装置は, グレア光源, コンピュータ, 17 インチ LCD スクリーン(発光部分の大きさ $272 \mathrm{~mm} \times 340 \mathrm{~mm}$ ), キーボード, 顎台から構成された。グレア光源は, 側空を模擬した $580 \mathrm{~mm} \times 580 \mathrm{~mm}$ の面光源とした. 内部を白色塗装した木製の箱 $(680 \mathrm{~mm} \times 680 \mathrm{~mm} \times 215 \mathrm{~mm})$ の中に, $16 \mathrm{~W}$ の昼白色の HF 蛍 光ランプ 16 本を取り付けた.木製の箱の開口面に乳白板を被せて, その周囲に $50 \mathrm{~mm}$ 幅の額縁を設けた. 蛍光ランプの安定器には, 調光機能がないため, ND フィルタを用いて発光面の輝度を調整し た，LCD スクリーンは，視標を提示するために用いた．グレア光源 と LCD スクリーンの位置関係は, 図 1 に示寸とおりである。キー ボードは，被験者が視標の検出を知らせるスイッチとして用いた． コンピュータは, 演算制御ソフトウェア (Mathworks 製 MATLAB) を介し，背景輝度の調整，視標の提示，反応時間の測定・記録を行 った。視標は, 反応時間を測定した既往研究 7)を参考にして, 寸法 : 16 ピクセル $\times 16$ ピクセル $(4.25 \mathrm{~mm} \times 4.25 \mathrm{~mm})$, 輝度 : $25 \mathrm{~cd} / \mathrm{m}^{2}$ の正方形の視標とし，視標の背景の輝度は $70 \mathrm{~cd} / \mathrm{m}^{2}$ とした，そのた め，視標の輝度コントラストは，0.64であった．視標輝度 $\left(\mathrm{L}_{\mathrm{t}}\right)$ と 背景輝度（ $\mathrm{L}_{\mathrm{b}} ）$ に対する輝度コントラスト $(\mathrm{C})$ は次式で定義した。

$$
C=\frac{L_{b}-L_{t}}{L_{b}}
$$

LCD スクリーンの中心から被験者の目の位置までの距離が 50 $\mathrm{cm}$ となるよう，顎台を用いて顔の位置を固定した，LCD スクリー ンから $14 \mathrm{~cm}$ 後方にグレア光源を設置した.つまり, 被験者とグレ ア光源の距離は $64 \mathrm{~cm}$ である.

\section{3. 実験条件}

実験中は，常に天井の照明器具を ND フィルタで覆って机上面照 度が $300 \mathrm{~lx}$ になるように調光した。

独立変数として, グレア光源の輝度と視標の偏心角を変化させ, それぞれ 5 水準用いた。 グレア光源の輝度は, 光源 off $\left(2 \mathrm{~cd} / \mathrm{m}^{2}\right)$, $3000 \mathrm{~cd} / \mathrm{m}^{2}, 6000 \mathrm{~cd} / \mathrm{m}^{2}, 9000 \mathrm{~cd} / \mathrm{m}^{2}, 12000 \mathrm{~cd} / \mathrm{m}^{2}$ の 5 水準とし た. 視標の提示位置 (偏心角) は, 視野中心から $0^{\circ}, 5^{\circ}, 10^{\circ}, 15^{\circ}, 23^{\circ}$ の 5 水準とした，実際の視標の提示位置は図 2 に示寸ように， 29 箇所 $\left\lceil 0^{\circ}: 1\right.$ 箇所, $5^{\circ}: 8$ 箇所, $10^{\circ}: 8$ 箇所, $15^{\circ}: 8$ 箇所, $23^{\circ}: 4$ 箇所 $]$ であった.いずれの偏心角においても視標提示の繰り返し回数を統 一寸るために $\left(16\right.$ 回), $0^{\circ}: 1$ 箇所 $\times 16$ 回, $5^{\circ}: 8$ 箇所 $\times 2$ 回, $10^{\circ}:$

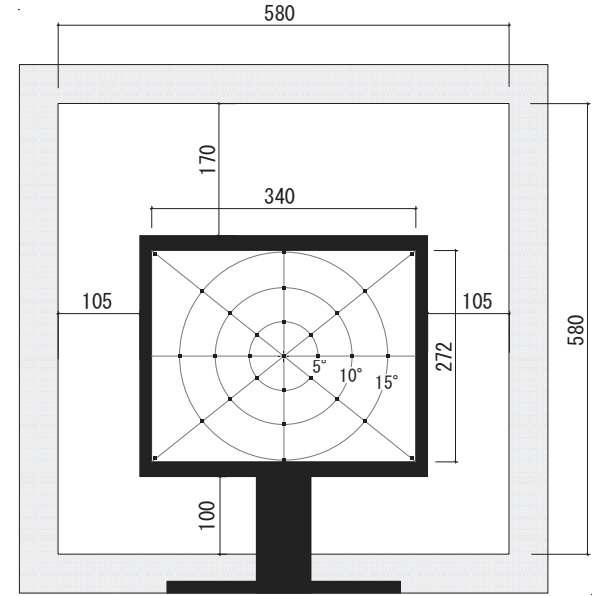

図 1 グレア光源と LCD スクリーンの位置関係 $(\mathrm{mm})$

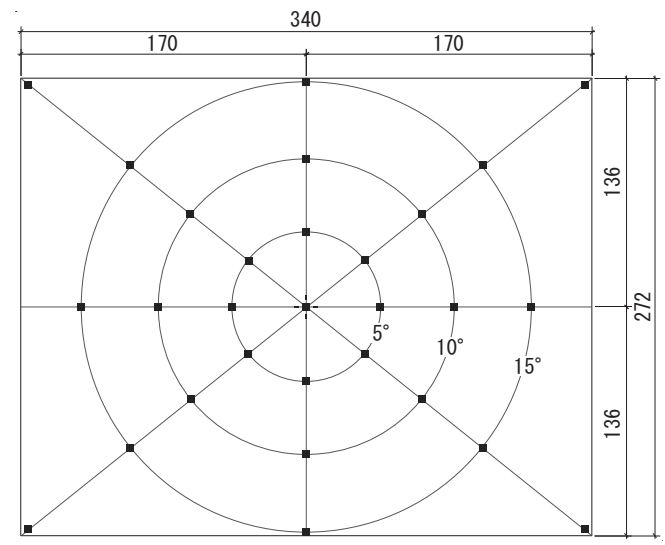

図 2 スクリーン上の視標の提示位置 $(\mathrm{mm})$

\begin{tabular}{|c|c|c|c|c|}
\hline No. & 性別 & 年齢 & 裸眼 or 矯正 & 実験時の視力 \\
\hline 1 & 女 & 22 & $\begin{array}{l}\text { 裸眼 } \\
\end{array}$ & $\mathrm{A}$ \\
\hline 2 & 女 & 21 & 裸眼 & $\mathrm{A}$ \\
\hline 3 & 女 & 22 & 矯正（眼鏡） & $\mathrm{A}$ \\
\hline 4 & 男 & 21 & 矯正（CL） & $\mathrm{A}$ \\
\hline 5 & 女 & 21 & 矯正 (CL) & $\mathrm{A}$ \\
\hline 6 & 男 & 22 & 裸眼 & $\mathrm{A}$ \\
\hline 7 & 男 & 22 & 裸眼 & $\mathrm{A}$ \\
\hline 8 & 男 & 21 & 裸眼 & $\mathrm{A}$ \\
\hline 9 & 女 & 22 & 矯正（CL） & B \\
\hline 10 & 男 & 22 & 裸眼 & B \\
\hline 11 & 男 & 20 & 矯正（眼鏡） & $\mathrm{A}$ \\
\hline 12 & 男 & 20 & 矯正（CL） & B \\
\hline 13 & 男 & 22 & 矯正（眼鏡） & B \\
\hline 14 & 男 & 22 & 裸眼 & $\mathrm{A}$ \\
\hline 15 & 男 & 21 & 裸眼 & $\mathrm{A}$ \\
\hline 16 & 女 & 22 & 裸眼 & $\mathrm{A}$ \\
\hline 17 & 女 & 21 & 矯正 (CL) & $\mathrm{A}$ \\
\hline 18 & 女 & 22 & 裸眼 & $\mathrm{A}$ \\
\hline 19 & 女 & 22 & 矯正 (CL) & B \\
\hline 20 & 女 & 21 & 裸眼 & $\mathrm{C}$ \\
\hline
\end{tabular}

8 箇所 $\times 2$ 回, $15^{\circ}: 8$ 箇所 $\times 2$ 回, $23^{\circ}: 4$ 箇所 $\times 4$ 回というように 調整した。 そのため, 実験では，計 80 個の視標についての反応時 間を，各輝度条件において測定した。輝度条件が 5 条件であったた め，各被験者につき合計 400 個の視標についての反応時間を測定し た.

従属変数として, 提示された視標に対する反応時間, 反応の有無 (見落とし率), 視野内のまぶしさ評価とした. 実験には, 予備知識 
のない $20 \sim 22$ 歳の学生, 男 10 名, 女 10 名の計 20 名（裸眼 11 , 眼鏡 3 、コンタクト 6) を被験者とした。表 1 に詳細を示す.

\section{4. 実験手順}

実験では，(1)実験者は，予めいずれかの輝度条件に設定した実験 室に, 被験者を一人ずつ案内し, 被験者を実験装置の前の椅子に着 席させた。被験者に実験手順について教示した。(2)実験者は, スク リーン画面の中央から被験者の目までの距離が $50 \mathrm{~cm}$ になるように 顎台の位置を調整し, 被験者に顎台に顎を乗せるように指示した。 (3)被験者は, LCD スクリーンの中央を注視し, キーボードのエンタ 一キーを押寸準備をして待機した。実験者は，被験者が準備できる のを待って視標検出実験を開始した。(4)視標検出実験が開始される と, 画面中央に黒の十字が現れた。被験者は, その十字を注視した まま, 画面上の種々の位置 (29 通り) に提示される視標を検出する や否やエンターキーを押した。(5)視標検出実験が終われば, 被験者 は，スクリーンの背景のグレア光源のまぶしさについてどのように 感じたかを表 2 の尺度に基づいて評価した。 (6)(1)から（5)を別のグレ ア光源の輝度条件について繰り返した.

コンピュータは，視標が提示されてからエンターキーが押される までの時間を反応時間として測定・記録した。また，被験者が視標 の出る位置とタイミングを予測することを防ぐため，視標を提示す る順序はランダムとし, 被験者がエンターキーを押してから次の視 標が表示されるまでの間隔は，1～5秒の範囲でランダムとした．な お，視標は提示されてから 3 秒経つと，自動的に消えるようになっ ている，その場合，被験者が視標を見落としたとみなした。

\section{3. 実験結果}

\section{1. まぶしさ評価}

実験結果の解析には, 被験者 20 名全員のまぶしさの評価データ を用いた．実験によって得られたまぶしさ評価についてグレア光源 の輝度を因子とした一元配置分散分析, 各輝度条件間における $\mathrm{t}$ 検 定を行い，統計的有意差を検証した。

図 3 に, 視野内のまぶしさに対する評価を示す．グレア光源がな い時に比べて, グレア光源がある時の方が，さらに，グレア光源の 輝度が高くなるほど，まぶしさの程度は高くなることがわかる，図 3 は，グレア光源が off になっているときも被験者がまぶしさを「感 じ始める」と評価している被験者もいたことを示しているが，これ は, LCD スクリーンの輝度によるまぶしさを評価したためであると 推察できる.

グレア光源の輝度に対するまぶしさ評価について一元配置の分散 分析を行った結果, グレア光源の輝度の主効果が確認できた $\left(\mathrm{p}<0.01^{* *}\right)$. また, 表 3 は, それぞれの輝度の条件間で行った $\mathrm{t}$ 検定の結果を示す.

\section{3．２．視標提示から検出するまでの反応時間}

実験結果の解析には, 被験者 20 名の反応時間を用いた。実験に よって得られた反応時間に対し,グレア光源の輝度と視標の偏心角 を因子とした二元配置分散分析を行ったままた，各輝度条件間にお ける $\mathrm{t}$ 検定と各偏心角条件間における $\mathrm{t}$ 検定を行った。 ただし, $\mathrm{t}$ 検定を行う際，視標の見落としにより反応時間の得られなかったも
表 2 まぶしさ評価尺度

\begin{tabular}{cc}
\hline 番号 & まぶしさ評価尺度 \\
\hline 8 & ひどすぎる, 耐え難い \\
7 & ひどすぎると感じ始める \\
6 & 不快である \\
5 & 不快であると感じ始める \\
4 & 気になる \\
3 & 気になり始める \\
2 & 感じられる \\
1 & 感じ始める \\
0 & 感じない \\
\hline
\end{tabular}

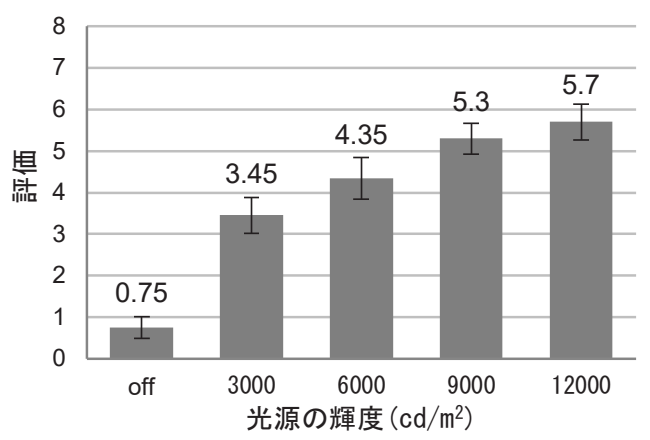

図 3 まぶしさ評価

表 3 各輝度条件間におけるまぶしさ評価に対する $\mathrm{t}$ 検定の結果

\begin{tabular}{ll}
\hline 輝度条件 $\left(\mathrm{cd} / \mathrm{m}^{2}\right)$ & $\mathrm{p}$ 值(両側) \\
\hline 光源 off と 3000 & $\mathrm{p}<0.01^{* *}$ \\
光源 off と 6000 & $\mathrm{p}<0.01^{* *}$ \\
光源 off と 9000 & $\mathrm{p}<0.01^{* *}$ \\
光源 off と 12000 & $\mathrm{p}<0.01^{* *}$ \\
3000 と 6000 & $\mathrm{p}<0.05^{*}$ \\
3000 と 9000 & $\mathrm{p}<0.01^{* *}$ \\
3000 と 12000 & $\mathrm{p}<0.01^{* *}$ \\
6000 と 9000 & $\mathrm{p}<0.05^{*}$ \\
6000 と 12000 & $\mathrm{p}<0.01^{* *}$ \\
9000 と 12000 & 有意差なし \\
\hline
\end{tabular}

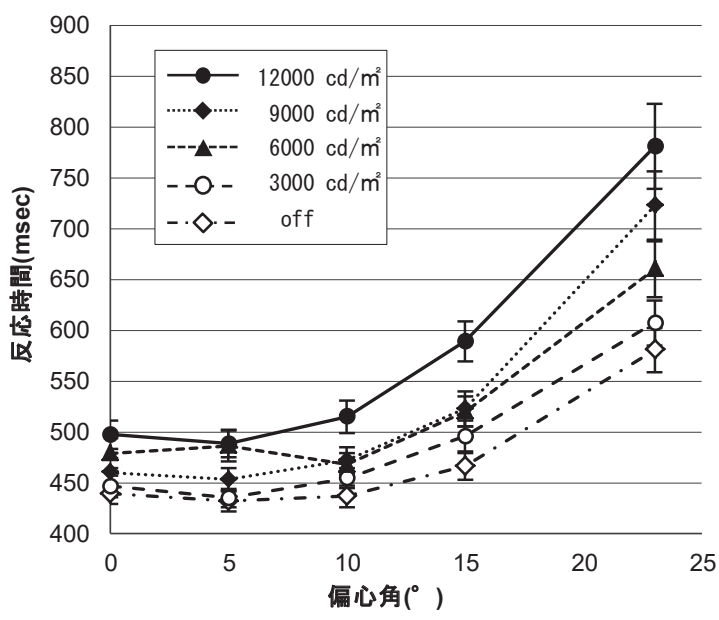

図 4 視標に対する反応時間

のについては反応時間 $3000 \mathrm{msec}$ とした.

図 4 は, グレア光源の輝度をパラメータとしたときの偏心角に対 する反応時間を示す．グラフから偏心角が大きくなるほど反応時間 が遅れること，グレア光源の輝度が高くなるほど反応時間が遅れる 
ことが明らかになった。

視標に対する反応時間についてグレア光源の輝度と視標の位置と を因子とし二元配置の分散分析を行った. その結果, グレア光源の 輝度, 視標の位置のいずれについても主効果 $(\mathrm{p}<0.01 * *)$ が認めら れた，表 4 は，輝度条件間の反応時間を比較したとき，表 5 は，偏 心角条件間の反応時間を比較した $\mathrm{t}$ 検定の結果を示す.グレア光源 の輝度については光源 off と $3000 \mathrm{~cd} / \mathrm{m}^{2}$ との間には統計的有意差は 見られなかった。一方，偏心角条件において $0^{\circ}, 5^{\circ}, 10^{\circ}$ の相互の 角度の間には統計的有意差は見られなかったが, $10^{\circ}, 15^{\circ}, 23^{\circ}$ の相 互の角度の間には統計的有意差が見られた。

\section{3．３．視標の見落とし率}

解析にあたり，視標が提示されてから被験者が 3 秒以内に検出で きなかった確率を視標の見落とし率と定義した。解析には, 被験者 20 名全員のデータを用いた. 視標の見落とし率に対してグレア光源 の輝度と視標の偏心角を因子とした二元配置の分散分析, 輝度条件 間における $\mathrm{t}$ 検定，偏心角条件間における $\mathrm{t}$ 検定を行い，統計的有 意差を検証した。

図 5 に，視標の見落とし率を示寸，横軸は偏心角，縦軸は見落と し率 $(\%)$ である．視標の偏心角が大きいところで見落とし率が高く なること, グレア光源の輝度が高いほど見落とし率が高くなること がわかる.

視標の見落とし率について, グレア光源の輝度と偏心角を因子と して二元配置の分散分析を行った結果，グレア光源の輝度の主効果 と偏心角の主効果が確認できた $\left(\mathrm{p}<0.01^{* *}\right)$. 表 6 は, 輝度条件間 について, 表 7 は, 偏心角条件間における視標の見落とし率を比較 した結果を示寸，輝度条件においては，反応時間と同様に光源 off と $3000 \mathrm{~cd} / \mathrm{m}^{2}$ との間には統計的有意差は見られなかった。また，偏 心角条件間においても $0^{\circ}, 5^{\circ}, 10^{\circ}$ の間には統計的有意差は見られ なかった， $10^{\circ}, 15^{\circ}, 23^{\circ}$ の間には統計的有意差が見られた.

\section{4. 考察}

4. 1. 不快グレアと減能グレアとの対応関係について

今回の実験から，視標検出の反応時間は，視標の偏心角が大きく なるほど遅くなること, また, グレア光源の輝度が高くなるほど遅 くなることが明らかになった．視標の見落とし率についても同様の 傾向が見られ，視標の偏心角が大きくなるほど，グレア光源の輝度 が高くなるほど，見落としが多くなる．いずれも，偏心角が大きい 視標ほど, グレアの影響を受けやすいことが明らかになった。

詳細を見ると, 反応時間, 視標の見落としのどちらにおいても, 偏心角条件の $0^{\circ}, 5^{\circ}, 10^{\circ}$ 間の統計的有意差はみられなったため, 0〜 $10^{\circ}$ の間では偏心角による視作業への影響はないものと考えら れる. $10^{\circ}, 15^{\circ}, 23^{\circ}$ の間には統計的有意差がみられ，偏心角が視作 業に影響することが明らかである.

注目すべきは, 反応時間, 視標の見落とし率のいずれにおいても, グレア光源の輝度について光源 off と $3000 \mathrm{~cd} / \mathrm{m}^{2}$ の間の統計的有意 差は見られなかったため, $3000 \mathrm{~cd} / \mathrm{m}^{2}$ 程度のグレア光源の輝度は, 視作業に影響しないと考えられることである。一方，まぶしさ評価 では統計的有意差が見られたことから，まぶしさ評価と視作業性と は対応しないことが示唆された。このことは, $9000 \mathrm{~cd} / \mathrm{m}^{2}$ と 12000
表 4 輝度条件間における反応時間に対する $\mathrm{t}$ 検定の結果

\begin{tabular}{ll}
\hline 輝度条件 $\left(\mathrm{cd} / \mathrm{m}^{2}\right)$ & $\mathrm{p}$ 值(両側) \\
\hline 光源 off $と 3000$ & 有意差なし \\
光源 off $と 6000$ & $\mathrm{p}<0.01^{* * *}$ \\
光源 off $と 9000$ & $\mathrm{p}<0.01^{* *}$ \\
光源 off $と 12000$ & $\mathrm{p}<0.01^{* * *}$ \\
3000 と 6000 & $\mathrm{p}<0.01^{* * *}$ \\
3000 と 9000 & $\mathrm{p}<0.01^{* * *}$ \\
3000 と 12000 & $\mathrm{p}<0.01^{* *}$ \\
6000 と 9000 & $\mathrm{p}<0.01^{* * *}$ \\
6000 と 12000 & $\mathrm{p}<0.01^{* * *}$ \\
9000 と 12000 & $\mathrm{p}<0.01^{* *}$ \\
\hline
\end{tabular}

表 5 偏心角条件間における反応時間に対する $\mathrm{t}$ 検定の結果

\begin{tabular}{ll}
\hline 扁心角条件 $\left(^{\circ}\right)$ & $\mathrm{p}$ 值(両側) \\
\hline 0 と 5 & 有意差なし \\
0 と 10 & 有意差なし \\
0 と 15 & $\mathrm{p}<0.01^{* *}$ \\
0 と 23 & $\mathrm{p}<0.01^{* *}$ \\
5 と 10 & $\mathrm{p}<0.1$ \\
5 と 15 & $\mathrm{p}<0.01^{* *}$ \\
5 と 23 & $\mathrm{p}<0.01^{* *}$ \\
10 と 15 & $\mathrm{p}<0.01^{* *}$ \\
10 と 23 & $\mathrm{p}<0.01^{* *}$ \\
15 と 23 & $\mathrm{p}<0.01^{* *}$ \\
\hline
\end{tabular}

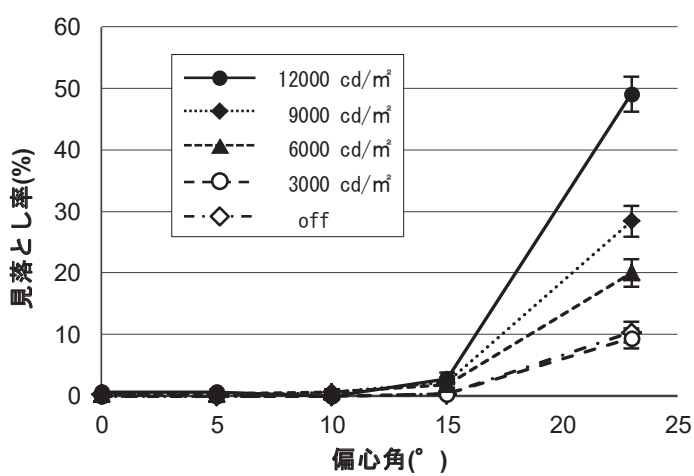

図 5 視標の見落とし率

表 6 各輝度条件間における視標の見落としに対する $\mathrm{t}$ 検定の結果

\begin{tabular}{ll}
\hline 輝度条件 $\left(\mathrm{cd} / \mathrm{m}^{2}\right)$ & $\mathrm{p}$ 值(両側) \\
\hline 光源 off と 3000 & 有意差なし \\
光源 off と 6000 & $\mathrm{p}<0.01^{* *}$ \\
光源 off と 9000 & $\mathrm{p}<0.01^{* *}$ \\
光源 off と 12000 & $\mathrm{p}<0.01^{* *}$ \\
3000 と 6000 & $\mathrm{p}<0.01^{* *}$ \\
3000 と 9000 & $\mathrm{p}<0.01^{* *}$ \\
3000 と 12000 & $\mathrm{p}<0.01^{* *}$ \\
6000 と 9000 & $\mathrm{p}<0.01^{* *}$ \\
6000 と 12000 & $\mathrm{p}<0.01^{* *}$ \\
9000 と 12000 & $\mathrm{p}<0.01^{* *}$ \\
\hline
\end{tabular}

表 7 偏心角条件間における視標の見落としに対する $\mathrm{t}$ 検定の結果

\begin{tabular}{ll}
\hline 偏心角 $\left(^{\circ}\right)$ & $\mathrm{p}$ 值(両側) \\
\hline 0 と 5 & 有意差なし \\
0 と 10 & 有意差なし \\
0 と 15 & $\mathrm{p}<0.01^{* *}$ \\
0 と 23 & $\mathrm{p}<0.01^{* *}$ \\
5 と 10 & 有意差なし \\
5 と 15 & $\mathrm{p}<0.01^{* *}$ \\
5 と 23 & $\mathrm{p}<0.01^{* *}$ \\
10 と 15 & $\mathrm{p}<0.01^{* *}$ \\
10 と 23 & $\mathrm{p}<0.01^{* *}$ \\
15 と 23 & $\mathrm{p}<0.01^{* *}$ \\
\hline
\end{tabular}


$\mathrm{cd} / \mathrm{m}^{2}$ の間において, 反応時間, 視標の見落とし率には有意差があ ったが，まぶしさ評価には有意差がないことからも確認された。

既往の研究結果で示されていたように, 中心視から周辺視に行く ほど錐体の密度が低く，視力が低下寸ることから 8)，視標の提示位 置の偏心角が大きくなるほど反応時間が遅くなったと考えられる.

また，偏心角が大きな視標においてグレア光源が提示されていな くても，複数回の見落としがあったことから，周辺視野での視標の 検出能力の低さが明らかである，さらに，視野内のグレアにより視 認性の低下が起こり, グレア光源の輝度が高くなるほど, 反応時間 に遅れが生じたと考えられる。

本研究では, 視標検出の反応時間を指標として用いることにより, 視野内のグレア光源が視作業に及ぼす影響を客観的に評価した。グ レア光源の影響は，その近傍の周辺視野に提示した視標の反応時間 だけでなく，中心視野に提示した視標の反応時間にも影響を及ぼし ていることがわかった

また，グレアによる不快感と視作業性とが対応していないことは 着目すべきである，視野内に高輝度面が存在する場合，不快だと感 じなくても視作業効率は低下寸る可能性があることを示唆している 日本人は，欧米人よりもグレアを感じにくい可能性があるため9), 知らず知らずのうちに視作業効率が低下しているのかもしれない.

\section{2. 空面のPGSV の計算}

本実験ではグレア光源が周辺視野に存在するが，これまで提案さ れている不快グレアの計算式は, 中心および周辺視野にグレア光源 が存在する状況下で求められたものである。被験者が評価した不快 グレアと提案されている計算式の程度の違いを比較するため, 本研 究では岩田らによって提案されている空面の不快グレアの指標であ る Predicted Glare Sensation Vote (PGSV)を計算した.

実験装置の空面の立体角を求めるにあたり，空面の中央部分が LCD スクリーンに隠れているため，空面の立体角（0.69 sr）から LCD スクリーンの立体角（0.37 sr）を引き算した。 その結果, 被 験者から見える空面の立体角 $\omega$ は， $0.32 \mathrm{sr}$ と算出した。また，実 験装置の机上面およびグレア光源背後の壁面の輝度は $42 \mathrm{~cd} / \mathrm{m}^{2}$, LCD スクリーンの輝度とグレア光源の枠部の輝度は $70 \mathrm{~cd} / \mathrm{m}^{2}$ であ った。作業中の被験者の目は LCD スクリーンの輝度に順応してい ると考えられ，グレア光源の枠部も同輝度であるため，算出に用い る背景輝度 $\mathrm{L}_{\mathrm{b}}$ は $70 \mathrm{~cd} / \mathrm{m}^{2}$ とした。これらの条件と実験に用いた空 面輝度をPGSVの計算式 ${ }^{1}$ に代入して各実験条件下の PGSVを算出 した.

表 8にPGSVの計算結果を示す. PGSV=0は、「ちょうど感じる」, PGSV=1 は,「ちょうど許容できる」，PGSV=2 は，「ちょうど不快 である」，PGSV=3は，「ちょうど耐えられない」にそれぞれ相当す る.なお，空面のグレア光源を点灯していない（off）条件について は，負の值の PGSV が算出されたが，この条件は PGSVの適用範 囲の外にあるため, 表 8 には掲載していない.

今回の実験では, 表 2 のまぶしさの評価尺度を用いたため, PGSV のそれとは異なる. 表 2 のまぶしさ評価尺度に基づいて, 図 3 の不 快グレアの評価結果を表 8 の PGSV の計算結果と比較すると, 表 8 のPGSVの計算結果に対応する評価よりも，やや不快グレアが感じ ない方向に評価されたことがわかる.このことは, 今回の実験では,
不快グレアの感度が高い中心視野が低輝度の LCD スクリーンによ り覆われていたことが原因であると考えられる。

表 8 各実験条件の PGSV の計算結果

\begin{tabular}{l|ccccc}
\hline 空面輝度 : Ls $\left(\mathrm{cd} / \mathrm{m}^{2}\right)$ & off & 3000 & 6000 & 9000 & 12000 \\
\hline PGSV & - & 1.40 & 2.36 & 2.92 & 3.32 \\
\hline
\end{tabular}

\section{4．３．グレア光源による光幕が視作業に及ぼす影響}

ここでは，本実験のデータの信頼性を既往研究と比較することに より考察する.

グレア光源による視対象の視認性の低下 (減能グレア)の原因は, 光源から眼に入射する光が眼球内で散乱することによって生じる光 幕が網膜像に重なって, 視対象と背景との輝度コントラストを下げ ることと考えられている 10),11)。この眼球内の光幕の量は, それと視 覚的に等価な視野内に重畳された光幕の輝度として定量的に評価さ れる．これは等価光幕輝度と呼ばれている．等価光幕輝度は，グレ ア光源の位置と観察者の目の位置での照度を変数とする関数で表さ れる.一般に, 各グレア光源と視線のな寸偏心角を $\theta_{i}{ }^{\circ}$ とて, 光源 による目の位置での照度を $E_{i} \mathrm{~lx}$ とする時，中心視に生じる等価光 幕輝度 : $L_{v} \mathrm{~cd} / \mathrm{m}^{2}$ は次式で表される 10),11),12).

$$
L_{v}=k \sum_{i=1}^{n} E_{i} \cdot \theta_{i}^{-a}
$$

ここで, $k, a$ は係数であり, それらの值は研究者によって異なる が，CIEでは， $(k, a)=(10,2)$ とすることで合意が得られている ${ }^{10)}$. また，等価光幕輝度の加法性が成立するとされ 13),14)，視野内に複数 のグレア光源が存在する場合は，中心視においてそれぞれのグレア 光源が生じる等価光幕輝度を加算する.

しかし，これらの等価光幕輝度の研究成果は，周辺視の評価には 適応できない，周辺視野に生じる等価光幕輝度について， Stiles と Crawford は，周辺視野に提示したグレア光源が周辺視野に生じる 光幕輝度を調べた ${ }^{15)}$. その結果, 周辺視野の光幕輝度についても (2) 式の関数が適応できること，ただし，係数は $(k, a)=(16,2)$ であるこ とを明らかにした。

今回，(2)式を用いて等価光幕輝度の分布を算出し，等価光幕輝度 が視標の輝度コントラストに及ぼす影響を調べた。その際，デジタ ルカメラの撮影よって得られる輝度画像ではなく, 輝度值を各ピク セルへ入力することによって作成した実験条件の輝度画像を用いて 光幕輝度を計算した，撮影による輝度分布測定では，高輝度の光源 が存在した際にカメラのレンズ特性によってフレアが発生し，既に 光幕が生じた状態となり, その画像を用いて光幕輝度を計算すると, 光幕輝度が二重に掛かってしまうためである。

輝度画像は，被験者が実験時に画面中央を固視している状態を想 定し, 実験装置の寸法や視点位置からの距離を基に視野角を算出し, 対応するピクセル数を求めて作成した．各部の輝度をつぎのように 設定した：LCD スクリーン $70 \mathrm{~cd} / \mathrm{m}^{2}$, 視標 $25 \mathrm{~cd} / \mathrm{m}^{2}$, グレア光源 の枠部 $70 \mathrm{~cd} / \mathrm{m}^{2}$ ，机や壁などの実験装置周辺部 $42 \mathrm{~cd} / \mathrm{m}^{2}$. グレア光 源の輝度条件ごとに輝度画像を作成した．輝度画像のサイズは 251 $\times 251$ ピクセル，水平および鉛直画角を $100^{\circ}$ として，グレア光源 の輝度の条件ごとに輝度画像を作成した，光幕輝度の加法性につい ては，すでに明らかにされているため 13$), 14)$, 中心視野 $2^{\circ}$ の範囲にお 
いて, 輝度画像を構成する各ピクセルの輝度情報からそれが影響す る被験者の目の位置の照度 $E_{i}$ を算出し, それを視野中心からの偏 心角 $\theta_{i}^{\circ}$ の 2 乗で除したものを加算することにより算出した．視野 中心から $50^{\circ}$ に相当する範囲の影響を考慮した. 周辺視野の範囲に おいても, 周辺視野の各ピクセルを中心として, その周辺 $50^{\circ}$ の範 囲のピクセルの輝度情報からそれが影響する被験者の目の位置の照 度 $E_{i}$ を算出し, それを中心からの偏心角 $\theta_{i}^{\circ}$ の 2 乗で除した值を加 算することにより算出した. (1)式において, 中心視野 $2^{\circ}$ の範囲には, $(k, a)=(10,2)$ を用い ${ }^{10)}$, 周辺視野には， $(k, a)=(16,2)$ を用いて計算 した ${ }^{15)}$.

表 9 は, 計算により求めた, 視標に掛かる等価光幕輝度とその影 響を加味した視標の輝度コントラストを示す. 表 9 に示す, 等価光 幕輝度による輝度コントラストの低下が鉛直面の視作業の視作業性 に及ぼす影響について考察するために, 本実験の輝度コントラスト と, Thibos 5 17)がグレア光源のない実験条件下で求めた周辺視野 の視標のコントラスト感度とを比較した。この既往研究は, 均一な 輝度のコンピュータ（またはオシロスコープ）画面を背景として， そこに空間周波数が異なる（0.5〜10 cpd）縞模様の視標を提示し， その視標のモジュレーションコントラスト $\left(\mathrm{C}_{\mathrm{m}}\right)$ の閾值を調べてい る. なお $\mathrm{C}_{\mathrm{m}}$ は, 縞模様の最大輝度 $\left(\mathrm{L}_{\max }\right)$ と最小輝度 $\left(\mathrm{L}_{\min }\right)$ につ いて, 次の式で定義される.

$$
C_{m}=\frac{L_{\max }-L_{\min }}{L_{\max }+L_{\min }}
$$

Thibos らは, 輝度が $80 \mathrm{~cd} / \mathrm{m}^{2}$ の背景に偏心角 30 度の位置に視標 を提示した。この背景輝度は, コンピュータ画面の輝度であると同 時に縞模様の視標の平均輝度であり, 今回の実験に用いた LCD ス クリーンの輝度 $70 \mathrm{~cd} / \mathrm{m}^{2}$ と概ね近い值といえる.

今回の実験に用いた視標は, 視角 0.5 度程度の正方形であったた め, 既往研究における空間周波数が $1 \mathrm{cpd}$ の視標に相当すると見な し, 既往研究の実験データからその空間周波数に対応する輝度コン トラストの閾值を読み取った。また, 別の既往研究 18) は, 空間周波 数が低い（例えば, $1 \mathrm{cpd}$ ) 視標に対しては, $30 \mathrm{~cd} / \mathrm{m}^{2}$ と $300 \mathrm{~cd} / \mathrm{m}^{2}$ の順応輝度の間で $\mathrm{C}_{\mathrm{m}}$ の閾值に差異は無いことを明らかにしている ため, グレア光源により順応輝度が高くなっている本実験に適応し て考察することにした。 その結果, Thibosらの実験データから, 偏 心角 30 度の視標について $\mathrm{C}_{\mathrm{m}}$ の閾值は 0.066 であることを読み取っ た.この $\mathrm{C}_{\mathrm{m}}$ の值は（3）式に示すように最大輝度と最小輝度を変数 として定義される， $\mathrm{C}_{\mathrm{m}}$ の值を本実験の考察に適用するために, 最大 輝度と最小輝度を（1）式の背景輝度と視標輝度に相当すると見な して輝度コントラスト（C）に置き換えることにした。その結果， 偏心角 30 度の視標の輝度コントラストの閾值は, 0.12 であること が明らかになった。さらに，この閾值を表 9 に示す本実験において 偏心角が近い, 23 度の視標の輝度コントラストと比較した. その結 果, グレア光源の輝度が上昇するにつれて視標の輝度コントラスト が閾值である 0.12 に近づいており，グレア光源の輝度が 12000 $\mathrm{cd} / \mathrm{m}^{2}$ の条件下では視標の輝度コントラストが閾值に達しているこ とが明らかになった。このことは，図 5 の見落とし率の結果が示す ように, 偏心角 23 度の視標に対してグレア光源の輝度が上昇する に連れて視標の見落とし率が高くなり, グレア光源の輝度が 12000 $\mathrm{cd} / \mathrm{m}^{2}$ の条件下で見落とし率が閾值（50\%）に達したことの信頼性
を裏付けた。

表 9 光幕輝度と輝度コントラストの計算結果

(VL: veiling luminance, $C$ : contrast)

\begin{tabular}{rccccccccccc}
\hline & \multicolumn{3}{c}{ off } & \multicolumn{3}{c}{$3000 \mathrm{~cd} / \mathrm{m}^{2}$} & \multicolumn{2}{c}{$6000 \mathrm{~cd} / \mathrm{m}^{2}$} & \multicolumn{2}{c}{$9000 \mathrm{~cd} / \mathrm{m}^{2}$} & \multicolumn{3}{c}{$12000 \mathrm{~cd} / \mathrm{m}^{2}$} \\
& VL & $\mathrm{C}$ & $\mathrm{VL}$ & $\mathrm{C}$ & $\mathrm{VL}$ & $\mathrm{C}$ & $\mathrm{VL}$ & $\mathrm{C}$ & \multicolumn{1}{c}{$\mathrm{VL}$} & $\mathrm{C}$ \\
\hline 0 deg. & 4.49 & 0.60 & 13.73 & 0.54 & 22.96 & 0.48 & 32.20 & 0.44 & 41.44 & 0.40 \\
5 deg. & 7.16 & 0.58 & 22.83 & 0.48 & 38.51 & 0.41 & 54.18 & 0.36 & 69.86 & 0.32 \\
$10 \mathrm{deg}$. & 7.00 & 0.58 & 27.48 & 0.46 & 47.97 & 0.38 & 68.47 & 0.32 & 88.97 & 0.28 \\
15 deg. & 6.40 & 0.59 & 39.97 & 0.41 & 73.59 & 0.31 & 107.20 & 0.25 & 140.82 & 0.21 \\
23 deg. & 4.34 & 0.61 & 82.85 & 0.29 & 161.43 & 0.19 & 240.01 & 0.15 & 318.59 & 0.12 \\
\hline
\end{tabular}

\section{5. 結論}

本研究の結果, 今回の実験条件の範囲において, つぎのことが明 らかになった。

・コンピュータ作業において, 鉛直なスクリーン面の視作業対象 の背景に高輝度の側空が存在すると視作業性が低下する，空面 の輝度が高くなるほど，視作業性の低下が著しくなり，空面に 近いスクリーンの周辺部ほど視作業性は低下する。本実験のデ 一タの信頼性は, コントラスト感度を求めた既往研究のデータ から裏付けられた。

・空面がある一定の輝度, $3000 \mathrm{~cd} / \mathrm{m}^{2}$ から $6000 \mathrm{~cd} / \mathrm{m}^{2}$ の間の輝度 に到達すると，視作業性が著しく低下する。このことから，コ ンピュータ・スクリーンなど, 鉛直面の視作業がある場合, ブ ラインドなどにより，空面輝度を $3000 \mathrm{~cd} / \mathrm{m}^{2}$ 以下になるように 制御するとよいと考えられる。

・空面がまぶしいことによる不快感と視作業効率の低下は必ずし も対応しない. 快適な作業空間を構築するために空設計をする 場合, 居住者の不快グレアの評価と視作業性を併せて考慮する 必要があると考えられる. 


\section{参考文献}

1) T. Iwata, M. Tokura: Examination of the limitations of predicted glare sensation vote (PGSV) as a glare index for a large source: towards a comprehensive development of discomfort glare evaluation, Lighting Research \& Technology, 30(2), pp.81-88, 1998.6

2) J. Wienold, J. Christoffersen: Evaluation methods and development of a new glare prediction model for daylight environments with the use of CCD cameras, Energy Build, 38, pp.743-57, 2006.7

3）伊藤大輔，岩田利枝，望月悦子：空スクリーンとブラインドの視環境性 能の比較, 日本建築学会環境系論文集, 73, 627, pp.573-579, 2008.5

4）岩田利枝, 佐々木良和, 伊藤大輔, 望月悦子 : 視野内平均輝度による総 量グレア範囲の抽出-不快グレアの対比効果と総量効果, その 2 , 日本建 築学会環境系論文集, 74, 635, pp.25-31, 2009.1

5）望月悦子, 伊藤大輔, 岩田利枝 : 空面内輝度が不快グレアに与える影響空スクリーンを用いた室内視環境の評価法に関する検討, その 4 , 日本建 築学会環境系論文集, 74, 637,pp.277-282, 2009.5

6) 中村一樹, 窪谷直彦, 小林茂雄, 中村芳樹, 乾正雄 : オフィスにおける 空面輝度抑制と眺望確保の関係 その 1.CRT 注視作業時におけるグレア 評価と空面輝度抑制, 日本建築学会大会学術講演梗概集, D, 環境工学, pp.1065-1066, 1994.7

7) M.S. Rea, M.J. Quellette : Visual performance using reaction times, Lighting Research \& Technology, 20(4), pp.139-153, 1988.12

8) H. Kolb, How the Retina Works, American Scientist, 91, pp.28-35, 2003.3

9) Y. Akashi, R. Muramatsu, S. Kanaya : Unified Glare Rating (UGR) and subjective appraisals of discomfort glare, Lighting Research \& Technology, 28(4), pp.199-206, 1996.12

10) Commission Internationale de l'Eclairage, CIE146 : CIE TC 1-50 report : CIE equations for disability glare, 2002

11) J.J. Vos : Disability glare - a state of the art report, CIE Journal, 3, pp.39-53, 1984

12) L.L. Holladay : The fundamentals of glare and visibility, Journal of Optical Society of America, 12, pp.271-319, 1926.4

13) W. Adrian, K. Eberback : On the relationship between the visual threshold and the size of the surrounding field, Lighting Research \& Technology, 1(4), pp.251-254, 1969.12

14) W. Adrian : Method of calculating required luminances in tunnel entrances, Lighting Research \& Technology, 8(2), pp.103-106, 1976.6

15) W.S. Stiles, B.H. Crawford : The effect of a glaring light source extra-foveal vision, Proceedings of Royal Society of London B, pp.255-280, 1937.4

16) J.M. Daitch, D.G. Green: Contrast sensitivity of the human peripheral retina, Vision Research, 9, pp.947-952, 1969.8

17) L.N. Thibos, D.L. Still, A. Bradley : Characterization of spatial aliasing and contrast sensitivity in peripheral vision, Vision Research, 36(2), pp.249-258, 1996.1

18) F. L. Van Nes, J. J. Koenderink, H. Nas, and M. A. Bouman : Spatiotemporal modulation transfer in the human eye, J Opt Soc Am 57(1), pp.1082-1088, 1967. 9

19) 加藤洋子, 明石行生, 菅野普：グレアの客観的評価-視作業効率に及ぼす 影響, 平成 22 年度（第 43 回）照明学会全国大会講演論文集, 148, 2010.8 


\section{THE EFFECT OF GLARE FROM WINDOWS \\ ON VISUAL PERFORMANCE FOR VERTICAL VDT TASKS}

Yoko KATO*, Yukio AKASHI** and Susumu SUGANO ***

* Grad. Stud., Dept. of Architecture and Building Engineering, School of Environment and Society, Tokyo Institute of Technology, M.Eng. ** Prof., Dept. of Architecture and Civil Engineering, Graduate School of Engineering, University of Fukui, Ph.D.

*** Corporate Research \& Development, Asahi Kasei Corporation, Ph.D.

In order to reduce global warming while maintaining occupants' health it is important to make the best use of daylight in interior spaces. To maintain comfortable interior environments while utilizing daylight it is necessary to control window luminance appropriately. To this end, many researchers have referred to discomfort glare from high-luminance windows. However, since recent office workers often perform visual tasks by using computer displays their visual performances are susceptible to high-luminance windows. Ocular light scatter covers the entire visual field of a worker, and therefore often reduces the luminance contrast of a target against its background.

The purpose of this study was to investigate how a high-luminance side window impairs visual performance of a computer task. Subjects were asked to detect targets presented at the central and peripheral visual field, and the subjects' response times were measured. In order to investigate the mechanisms of how window luminance affects target detections, veiling luminance on each target caused by the window was calculated under each of the experimental conditions. The findings of the study are listed below.

1) The high-luminance window behind the computer display significantly impaired the detection performance of targets presented on the computer display. As the luminance of the window increased, the visual performance was decreased. The validity of the experimental dataset was confirmed by comparing the dataset with existing experimental data.

2) When window luminance exceeded a certain luminance between $3000 \mathrm{~cd} / \mathrm{m}^{2}$ and $6000 \mathrm{~cd} / \mathrm{m}^{2}$, visual performance was deteriorated significantly. This implies that window luminance should be reduced to lower than $3000 \mathrm{~cd} / \mathrm{m}^{2}$ for computer tasks.

3) Evaluations of discomfort glare did not necessarily correspond to visual performance. Therefore, in order to design windows for efficient task environments it is important to minimize the effects of windows on discomfort glare and visual performance. 